\title{
Abnormalities in the Adrenergic Control and the Rate of Lipolysis in Isolated Human Subcutaneous Adipose Tissue in Diabetes Mellitus
}

\author{
P. Arner and J. Östman \\ Department of Internal Medicine, Huddinge University Hospital, Huddinge, Sweden
}

Summary. Subcutaneous adipose tissue was obtained from 9 patients with untreated diabetes mellitus and from 13 obese nondiabetics. After incubation with isoprenaline or noradrenaline, glycerol release and tissue cyclic AMP (cAMP) were determined. Basal glycerol release was twice as rapid from the diabetic adipose tissue. With isoprenaline, the cAMP concentration and the glycerol production was significantly higher in the diabetic adipose tissue. Noradrenaline did not increase glycerol production or cAMP concentration in the diabetic adipose tissue. Subcutaneous adipose tissue was also removed from the diabetics after antidiabetic treatment. Basal lipolysis was significantly reduced and noradrenaline significantly increased both glycerol release and cAMP production. With isoprenaline, cAMP production and glycerol release were significantly less after antidiabetic treatment than in the untreated state. The data provide evidence for increased $\alpha$ - as well as $\beta$-adrenergic receptor sensitivity in human subcutaneous adipose tissue of untreated diabetic patients.

Key words: Adipose tissue, diabetes mellitus, isoprenaline, noradrenaline, glycerol release, cyclic AMP.

The accelerated lipid mobilisation from the fat depots in human diabetes mellitus is well established by measurements of free fatty acids (FFA) and glycerol in plasma (see 13 for references) as well as by studies on subcutaneous adipose tissue in vitro $[7,8,12,18,32]$. Insulin deficiency and/or increased action by adipokinetic hormone are generally considered to be the pathophysiological background. In human adipose tissue the catecholamines noradrenaline (NA) and adrenaline are unique, with respect to their prominent lipolytic actions, in comparison with a number of other hormones [9] and to their ability to produce both $\beta$-adrenergic (stimulatory) and $\alpha$-adrenergic effects (inhibitory) on lipolysis $[10,33]$. To study the apparent changes in the insulincatecholamine interrelationship which occur in the lipid metabolism of human adipose tissue in diabetes mellitus the following experiments were performed. Subcutaneous adipose tissue was obtained from 1) patients with newly diagnosed diabetes mellitus before and after antidiabetic treatment and 2) from a group of non-diabetic control patients admitted to the hospital because of obesity. Adipose tissue was incubated in the absence or in the presence of either isoprenaline (ISNA) or NA. The release of glycerol to the incubation medium and the maximal tissue levels of cyclic AMP (cAMP) were determined. The diabetic patients constituted a heterogeneous group as regards the type of disease, kind of antidiabetic treatment and body-weight. In other words, this study was undertaken to get a general idea of the adrenergic control of lipolysis in diabetes mellitus in vitro.

\section{Material and Methods}

\section{Patients}

The nine newly diagnosed diabetic patients included 2 with juvenile-onset and 7 with maturity-onset type of diabetes. The duration of symptoms was from 3 to 6 months. All were initially studied as inpatients. Relevant clinical data are presented in Table 1 . Three patients (Nos. 5, 6, 7) had non-acidotic ketosis and 4 (Nos. 3, 4, 6, 9) had high levels of serum triglycerides and one (No. 1) had increased level of serum choles- 
Table 1. Clinical data of the patients with diabetes mellitus ${ }^{a}$

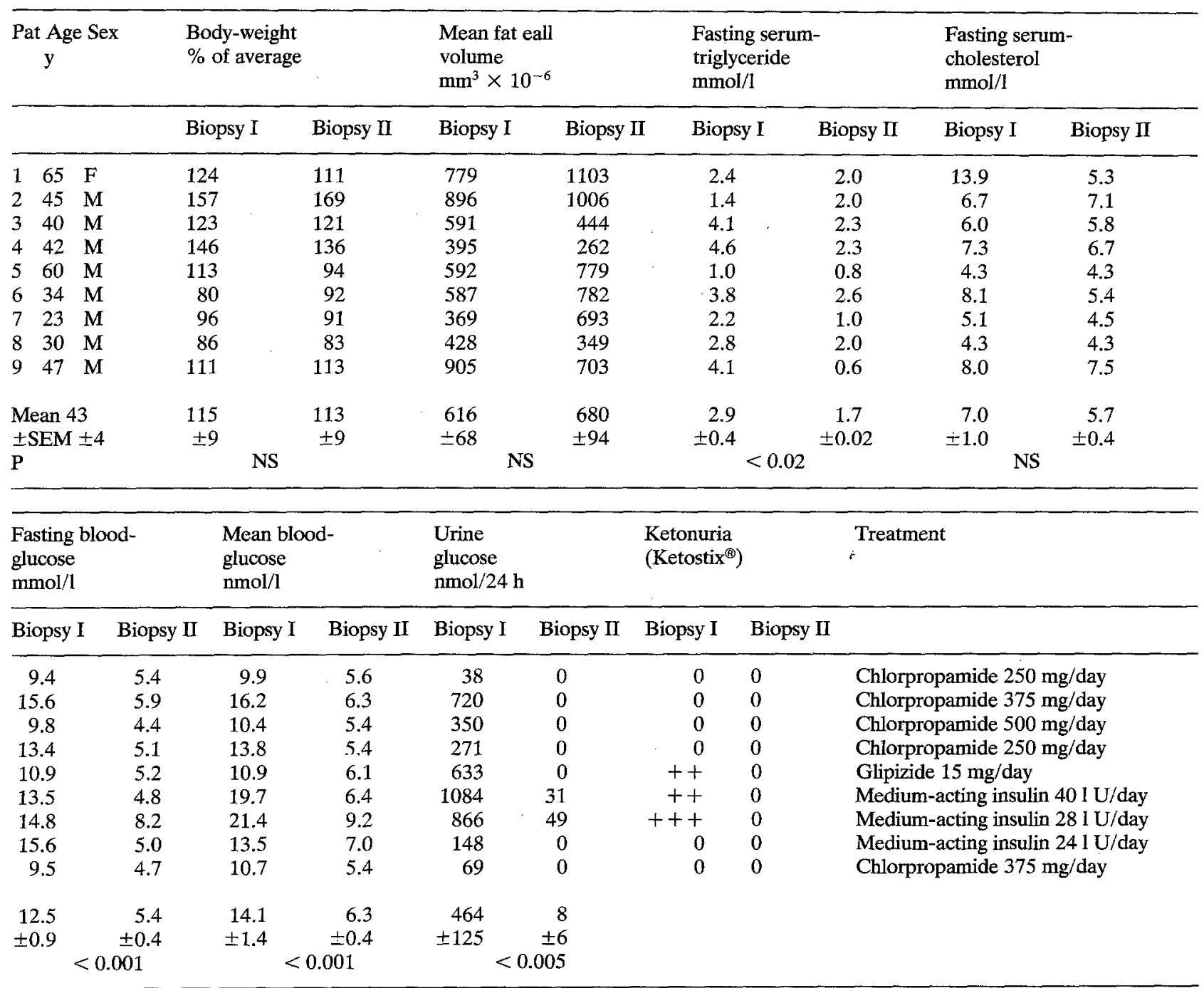

a Biopsy I is before and II after treatment. Fasting blood-glucose, serum-triglyceride and serum-cholesterol was determined at $7 \mathrm{a}$. $\mathrm{m}$. on the day of biopsy. The mean blood-glucose level was calculated from three to four determinations during $24 \mathrm{~h}$ preceding the biopsy. The production of urine-glucose was determined on urine collected during $12 \mathrm{~h}$ before and after biopsy. Body weight in percentages of average was calculated from tables computed by Documenta Geigy [15]. P is probability of differences of biopsy I and II (paired t-test). NS $==$ not significant

Table 2. Clinical data of 13-non-diabetic, obese control patients ${ }^{\mathrm{a}}$

\begin{tabular}{|c|c|c|c|c|c|c|c|}
\hline & $\begin{array}{l}\text { Age } \\
y\end{array}$ & Sex & $\begin{array}{l}\text { Body-weight } \\
\% \text { of average }\end{array}$ & $\begin{array}{l}\text { Mean fat cell } \\
\text { volume } \\
\mathrm{mm}^{3} \times 10^{-6}\end{array}$ & $\begin{array}{l}\text { Serum- } \\
\text { triglyceride } \\
\mathrm{mmol} / 1\end{array}$ & $\begin{array}{l}\text { Serum- } \\
\text { cholesterol } \\
\mathrm{mmol} / 1\end{array}$ & $\begin{array}{l}\text { Glucose tolerance } \\
\text { k-value } \\
\% / \mathrm{min}\end{array}$ \\
\hline $\begin{array}{l}\text { Mean } \\
\pm \text { SEM } \\
\mathrm{P}_{\text {vs }}\end{array}$ & $\begin{array}{r}34 \\
\pm 3\end{array}$ & $10 \mathrm{~F} / 3 \mathrm{M}$ & $\begin{array}{l}181 \\
\pm 11\end{array}$ & $\begin{array}{r}861 \\
\pm 55\end{array}$ & $\begin{array}{r}2.8 \\
\pm 0.5\end{array}$ & $\begin{array}{r}5.8 \\
\pm 0.2\end{array}$ & $\begin{array}{r}1.36 \\
\pm 0.11\end{array}$ \\
\hline $\begin{array}{l}\text { Diabetic } \\
\text { group }\end{array}$ & NS & & $<0.001$ & $<0.02$ & NS & NS & \\
\hline
\end{tabular}

a Cholesterol and triglycerides were determined on fasting venous blood-samples by the hospital's routine procedure. The $k$-value was determined according to Ikkos \& Luft (23). Body-weight in percentage of average was calculated from tables computed by Documenta Geigy (15). $P$ denotes the significance of differences between the means of the control patients and the untreated diabetic patients in Table 1. NS $=$ not significant 
terol. They were all on unrestricted hospital diet and did not receive any antidiabetic treatment before the first study. A fat biopsy specimen was taken at 8 a.m. after an overnight fast.

A second study was undertaken when the diabetes was considered to be well controlled for at least two months on the basis of stable body-weight, normal or slightly elevated fasting blood-glucose level and essential freedom from glucosuria. Three patients (Nos. $6,7,8)$ were treated with insulin and the others with sulphonylurea drugs. On average, there was a small and significant $(\mathrm{p}<0.02)$ decrease of the level of serum triglycerides but serum cholesterol and the fat cell size were not significantly changed while the patients were on antidiabetic therapy (Table 1). Then the patients were again admitted to the hospital. At 8 a. $\mathrm{m}$., and before they had received antidiabetic therapy, a second biopsy was performed after an overnight fast. All but two of the diabetic patients were otherwise in good health. Patient No. 1 had mild hypertension, which was treated with $50 \mathrm{mg}$ of chlorthalidone per day. Patient No. 6 had an acute myocardial infarction between the two studies. He was treated with $400 \mathrm{mg}$ of phenytoin per day because of ventricular ectopic beats.

The control group comprised 13 adult patients admitted to the hospital because of obesity. They showed no evidence of hepatic, renal or endocrine disorder and had a normal glucose tolerance [23]. One of them had mild hypertension and epilepsy and was treated with $50 \mathrm{mg}$ of chlorthalidone and $400 \mathrm{mg}$ of phenytoin per day. All were on unrestricted diet before the study. None was subjected to attempts at weight reduction in the 3 months prior to the study. Clinical data of the control patients are presented in Table 2. On average their age and serum cholesterol and serum triglyceride levels did not differ from those of the diabetic patients. However, 4 control patients had elevated serum levels of triglycerides and cholesterol, corresponding to Type IV hyperlipoproteinaemia according to the classification of Fredrickson et al. [17]. The mean fat cell volume was significantly larger $(p<0.02)$ in adipose tissue of the controls $\left(861 \mathrm{~mm}^{3} \times 10^{-6}\right)$ than in that of the diabetics $\left(616 \mathrm{~mm}^{3} \times 10^{-6}\right)$. The body-weight was almost $60 \%$ higher in the control patients than in the diabetics when expressed as a percentage of the average and the difference was significant $(\mathrm{p}<0.001)$. After one night of fasting a fat biopsy specimen was taken at $8 \mathrm{a} . \mathrm{m}$. on the following morning.

All patients were weighed on standard scales accurate to within $0.1 \mathrm{~kg}$. The weight as a percentage of the average weight of a normal population was calculated from the tables computed by Documenta Geigy [15]. The biopsy procedure has been approved by the Ethi- cal Committee of the Karolinska Institute. Details of the study were explained to each patient and informed consent was obtained.

\section{Methods}

Subcutaneous adipose tissue was excised from the upper lateral part of the thigh, which was anaesthetised with prilocaine chloride as described in detail before [3]. Adipose tissue was divided into portions of approximately $50 \mathrm{mg}$ each, preincubated for $30 \mathrm{~min}$ in Krebs-Henseleit bicarbonate (KHB) buffer containing $40 \mathrm{mg} / \mathrm{ml}$ of dialysed bovine serum albumin (Armour Pharmaceutical Co. Eastbourne, England; Lot No. R 970) and then incubated in $1 \mathrm{ml}$ of medium of the same type for $2 \mathrm{~h}$. After incubation, two aliquots $(0.1 \mathrm{ml})$ of the medium were removed for glycerol determination as described by Wieland [29] and modified by Chernick [14]. The pre-incubation and incubation procedure have been described in detail [31].

The intracellular cAMP concentration was determined in adipose tissue pre-incubated for $30 \mathrm{~min}$ in $\mathrm{KHB}$-buffer, $\mathrm{pH} 7.4$, containing $10 \mathrm{mmol} / \mathrm{l}$ of theophylline (ACO, Sweden) and then incubated for 10 min in fresh medium of the same type. Albumin was not included in these experiments, since it has been shown to interfere strongly with the assay for cAMP [4, 27]. Incubation and pre-incubation were carried out in glass vessels with $50 \mathrm{ml}$ of medium per $\mathrm{g}$ of adipose tissue. It was observed from several experiments that the maximal tissue level of cAMP occurs after about $10 \mathrm{~min}$ of incubation [2] and that the omission of albumin from the buffer did not lead to accumulation of tissue FFA in amounts that could interfere with the production or degradation of cAMP in human adipose tissue incubated for $10 \mathrm{~min}$ under basal or stimulated conditions [1]. We have observed that cAMP could not usually be measured in human subcutaneous adipose tissue when tissue pieces weighing less than $100 \mathrm{mg}$ wet weight were analysed without prior incubation [1]. In the present study, the amount of adipose tissue obtained from one biopsy allowed the use of tissue samples weighing only $50-75 \mathrm{mg}$ of wet weight for a single incubation. Furthermore, we have recently observed [2] that the cAMP level significantly decreases during incubation in a basal medium. Therefore, the phosphodiesterase inhibitor theophylline was added to enable measurement of the maximal effect of catecholamines on the tissue level of cAMP as well as the basal tissue level of cAMP.

Agents added in vitro were noradrenaline bitartrate (Astra, Sweden) and isopropylnoradrenaline$\mathrm{HCl}$ (Winthrop, England). Both agents were dis- 

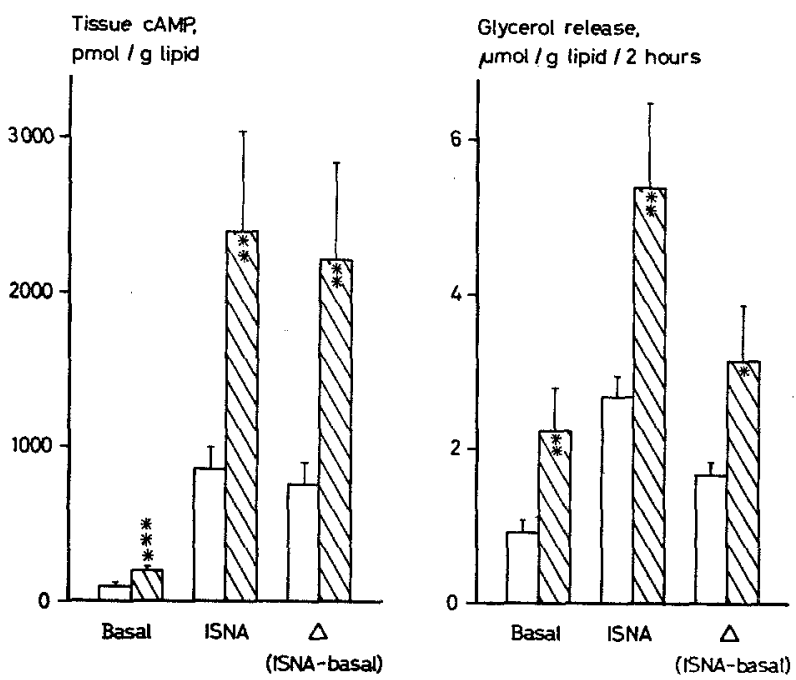

Fig. 1. Effect of isoprenaline (ISNA) on the metabolism of diabetic and non-diabetic adipose tissue: Subcutaneous adipose tissue was excised from 9 newly diagnosed diabetics before antidiabetic treatment (hatched bars) and from 13 obese non-diabetic patients (open bars). Adipose tissue was pre-incubated and incubated under basal conditions and in the presence of $6 \times 10^{-6} \mathrm{~mol} / 1$ of ISNA. Tissue cyclic AMP (cAMP) was determined at $10 \mathrm{~min}$ and glycerol release at $2 \mathrm{~h}$ of incubation. Values are Mean \pm SEM and expressed per $\mathrm{g}$ of lipid weight. In the individual experiments four to five fat portions were used for each type of incubation. The statistical symbols are for unpaired comparison of the values for the diabetics with those of the non-diabetic patients $\left({ }^{* * *}=\mathrm{p}<0.005,{ }^{* *}=\mathrm{p}<0.02,{ }^{*}=\mathrm{p}<\right.$ 0.05 )
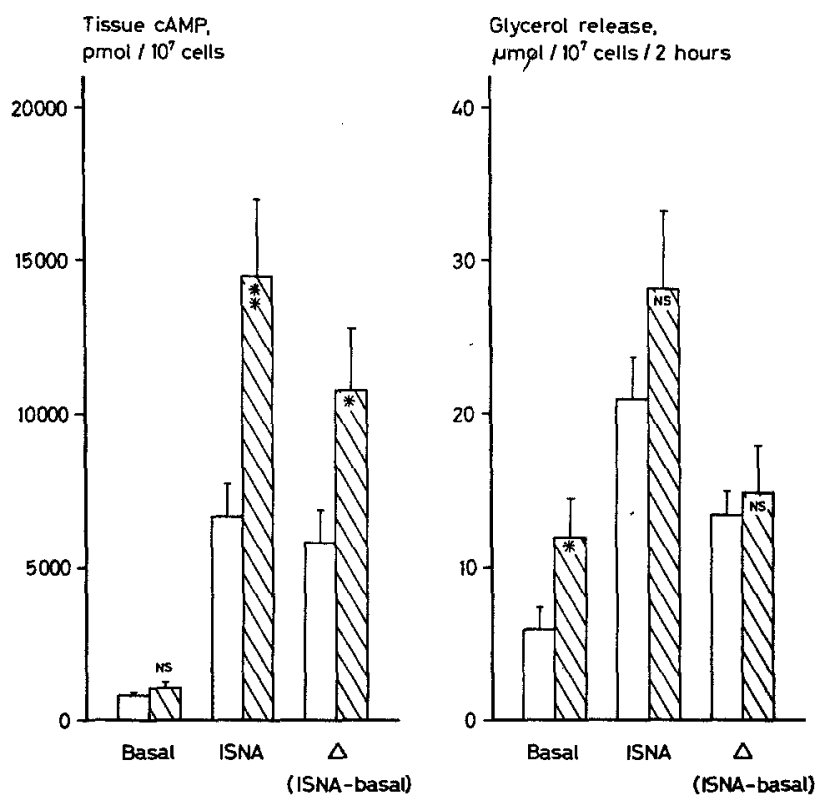

Fig. 2. This figure shows the same experiments as in Figure 1 but the values for cyclic AMP and glycerol release are expressed per $10^{7}$ cclls. The symbols are the same as in Figure 1 except that NS $=$ not significant solved in water and added to the incubation medium in portions of $0.1 \mathrm{ml}$, or directly dissolved in the incubation medium, to give a final concentration of $6 \times$ $10^{-6} \mathrm{~mol} / \mathrm{l}$. This concentration is known to give a maximal effect on the rate of lipolysis $[2,16]$. All incubations and pre-incubations were carried out at $37^{\circ} \mathrm{C}$ in a water-bath cycling at $40 / \mathrm{min}$. Air was used as the gas phase.

\section{Assay of Intracellular cAMP}

cAMP was determined by a modification of the protein-binding method of Gilman [19], as described in detail elsewhere [4]. cAMP-binding protein and ${ }^{3} \mathrm{H}$ adenosine-3', 5'-monophosphate, cyclic ammonium salt (spec. act. $15 \mathrm{mCi} / \mathrm{mmol}$ ) were obtained from Boehringer-Mannheim's "kit assay" for cAMP (Cat. No. 16289). Protein-kinase inhibitor was purchased from Sigma (U. S. A.).

\section{Determination or Cell Size}

Two fat specimens, weighing about $30 \mathrm{mg}$ each, were used for the determination of the cell diameter according to the procedure developed by Sjöström et al. [28]. 100 cells were measured and the mean cellular triglyceride content was calculated from the average diameter and the SD of the diameter, according to the formula developed by Hirsch and Gallian [22]. The number of fat cells incubated was calculated using the mean cellular triglyceride weight and the total triglyceride content of the fat portions.

\section{Statistical Analysis}

The values given comprise the mean and the standard error of the mean (SEM). Significance of the differences was calculated by Student's paired or unpaired t-test.

\section{Results}

The basal rate of glycerol release was about twice as rapid from adipose tissue of the untreated diabetics as from that of the control patients (Figs. 1 and 2), although the latter had a mean fat cell volume which was significantly larger $(p<0.02)$ than that of the diabetics (Table 2). The difference in the rate of lipolysis was significant when calculated per lipid weight $(\mathrm{p}<$ 0.02 in Fig. 1$)$ as well as per cell number ( $p<0.05$ in Fig. 2). The basal tissue level of cAMP was also higher in adipose tissue of the diabetics, but only when calculated per lipid weight ( $\mathrm{p}<0.005$ in Fig. 1).

The addition of $6 \times 10^{-6} \mathrm{~mol} / \mathrm{l}$ of ISNA increased significantly the rate of glycerol release $(\mathrm{p}<0.01)$ as well as the cAMP level $(\mathrm{p}<0.005)$ in adipose tissue of both patient groups (Figs. 1 and 2). When expressed per lipid weight (Fig. 1), the total release of glycerol in 
Table 3. Tissue levels of cyclic AMP (cAMP) and glycerol release by subcutaneous adipose tissue in vitro, obtained from 6 patients with diabetes mellitus before and after treatment ${ }^{\mathrm{a}}$

\begin{tabular}{|c|c|c|c|c|c|c|c|c|c|c|}
\hline \multirow{2}{*}{$\begin{array}{l}\text { Type of } \\
\text { experiment }\end{array}$} & \multicolumn{5}{|c|}{ Tissue cAMP, pmol $/ 10^{7}$ cells } & \multicolumn{5}{|c|}{ Glycerol release, $\mu \mathrm{mol} / 10^{7}$ cells $/ 2$ hours } \\
\hline & Basal & ISNA & $\mathbf{P}$ & NA & $\mathbf{P}$ & Basal & ISNA & $\mathbf{P}$ & NA & $\mathbf{P}$ \\
\hline Before & 1186 & 14499 & & 1305 & & 11.9 & 28.0 & & 12.1 & \\
\hline treatment & \pm 188 & \pm 3297 & $<0.005$ & \pm 221 & NS & \pm 2.5 & \pm 5.0 & $<0.001$ & \pm 2.8 & NS \\
\hline After & 1053 & 7502 & & 1683 & & 3.7 & 13.0 & & 7.5 & \\
\hline treatment & \pm 200 & \pm 2102 & $<0.02$ & \pm 276 & $<0.01$ & \pm 0.5 & \pm 1.3 & $<0.001$ & \pm 0.9 & $<0.005$ \\
\hline $\mathbf{P}_{1}$ & NS & $<0.05$ & & NS & & $<0.02$ & $<0.02$ & & NS & \\
\hline
\end{tabular}

a Adipose tissue was incubated in the absence or in the presence of $6 \times 10^{-6} \mathrm{~mol} / 1$ of isoprenaline (ISNA) or noradrenaline (NA). Tissue cAMP was determined at $10 \mathrm{~min}$ and the glycerol after $2 \mathrm{~h}$ of incubation. $\mathrm{P}$ is probability of differences of basal vs ISNA or NA, before or after treatment and before vs after treatment. NS $=$ not significant. $n=3$ to 5 in the individual experiments. Values are mean $\pm S E M$

the presence of ISNA $(p<0.02)$ as well as the ISNAinduced glycerol release over basal $(p<0.05)$ was significantly higher in the diabetic patients. When expressed per lipid weight (Fig. 1) or per cell number (Fig. 2), the tissue concentration of cAMP in the presence of ISNA ( $p<0.02$ in Figs. 1 and 2$)$ as well as the ISNA-induced increase of tissue cAMP over the basal level ( $p<0.02$ in Fig. 1 and $p<0.05$ in Fig. 2) was significantly higher in the diabetic patients.

$\mathrm{NA}, 6 \times 10^{-6} \mathrm{~mol} / 1$, did not increase significantly either the tissue level of cAMP or the rate of lipolysis in the untreated diabetics (Fig. 3). In the control group, however, NA increased significantly the adipose tissue concentration of cAMP by $60 \%$ (p < $0.001)$ and the glycerol release by $50 \%(\mathrm{p}<0.001)$, as shown in Figure 3. In uncharted experiments, $6 \times$ $10^{-5} \mathrm{~mol} / 1$ of NA was also without effect on the rate of lipolysis of adipose tissue of untreated diabetics.

Table 3 shows the effect of antidiabetic therapy on cAMP and glycerol release from subcutaneous adipose tissue obtained from the diabetic patients. Whereas the basal rate of glycerol release decreased significantly $(\mathrm{p}<0.02)$, there was no change in the basal tissue level of cAMP. After antidiabetic therapy the response to NA was normalised. Thus, a significant $(\mathrm{p}<0.005)$ increment in the rate of glycerol release of about $100 \%$ was observed and the tissue level of cAMP increased significantly $(p<0.01)$ by about $60 \%$. In the presence of ISNA both the rate of glycerol release and the tissue level of cAMP were $50 \%$ lower after treatment. These findings were also significant $(\mathrm{p}<0.02$ for glycerol and $\mathrm{p}<0.05$ for cAMP).

\section{Discussion}

\section{Basal Lipolysis}

The basal rate of lipolysis was about twice as rapid in adipose tissue of the untreated diabetics as in the
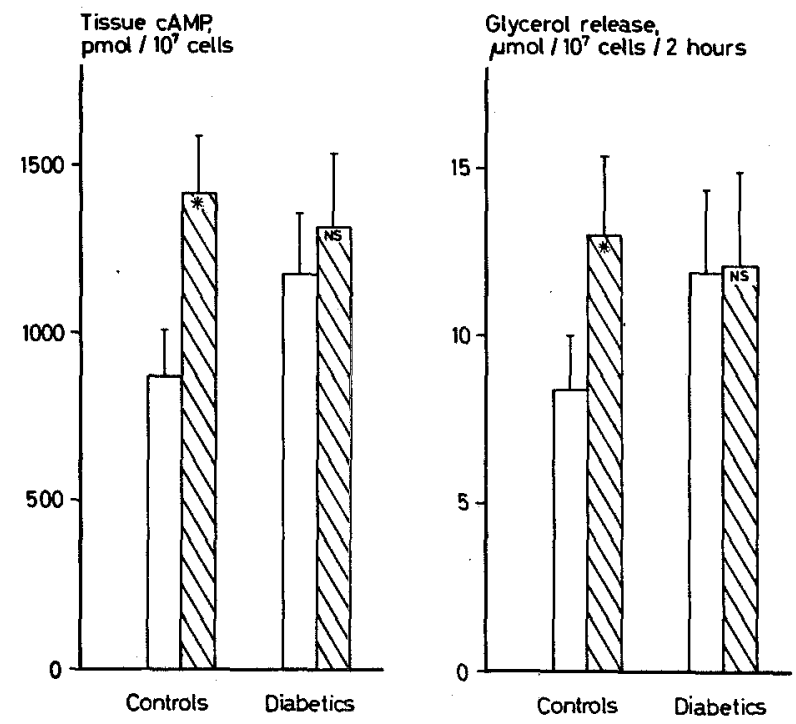

Fig. 3. Effect of noradrenaline (NA) on the metabolism of diabetic and non-diabetic adipose tissue: Subcutaneous adipose tissue was obtained from 9 newly diagnosed diabetics before receiving antidiabetic treatment and from 10 obese, non-diabetic control patients. Adipose tissue was pre-incubated and incubated under basal conditions (open bars) and in the presence of $6 \times 10^{-6} \mathrm{~mol} / 1$ of NA (hatched bars). Tissue cyclic AMP (cAMP) and glycerol release were determined at $10 \mathrm{~min}$ and $2 \mathrm{~h}$, respectively, of incubation. Four to five fat portions were used for each type of incubation in the individual experiments. Values are Mean \pm SEM and expressed per $10^{7}$ cells. The statistical symbols are for paired comparison of basal with NA-induced values $\left({ }^{*}=\mathrm{p}<0.001, \mathrm{NS}=\right.$ not significant)

control group (Figs. 1 and 2), which confirms earlier observations made on juvenile $[7,12,32]$, maturityonset diabetics [8] and obese diabetics [18]. Differences in the basal concentration of tissue cAMP are not a likely explanation of the findings relating to basal lipolysis. No differences existed between the diabetic and non-diabetics groups when CAMP was expressed on a cellular basis (Fig. 2). Furthermore, when the diabetic patients were on antidiabetic therapy, the rate of basal lipolysis was significantly reduced by $70 \%,(p<0.02)$, while the basal tissue 
level of cAMP was unchanged (Table 3 ). It is thus possible that, in untreated diabetics, basal lipolysis is increased because of a direct effect on the level of protein kinase or triglyceride lipase. However, stromal cAMP might have influenced the measured basal tissue level of the nucleotide.

\section{Catecholamine-Induced Lipolysis}

The mean lipolysis induced by ISNA was of similar rate in adipose tissue of untreated diabetics and control patients when expressed per cell number (Fig. 2), but increased in diabetics when expressed per lipid weight (Fig. 1). However, the ISNA-induced rate of lipolysis per number of cells was significantly $(\mathrm{p}<$ 0.02 ) reduced by one-half in adipose tissue of the diabetics when they were on antidiabetic treatment (Table 3). Irrespective of the reference system, the $\beta$-adrenergic production of cAMP induced by ISNA was increased in adipose tissue of untreated diabetics (Figs. 1 and 2), results which could partly be due to inhibited phosphodiesterase activity, which is known to be decreased in adipose tissue of diabetics [24]. If decreased activity of phosphodiesterase is the only explanation, changes in the ISNA-induced cAMPlevel would be followed by concomitant changes in the basal level of cAMP. However, the ISNA-induced tissue level of cAMP was significantly $(p<0.05)$ reduced by one-half in adipose tissue of diabetic patients on antidiabetic therapy when compared with the untreated state, while the basal level of cAMP was unchanged (Table 3). Thus, the findings with ISNA and cAMP seem to indicate increased $\beta$-adrenergic receptor sensitivity as well as decreased phosphodiesterase activity in subcutaneous adipose of untreated diabetics.

Addition of NA failed to increase lipolysis in adipose tissue of untreated diabetics in contrast to the effect of NA on adipose tissue of control patients (Fig. 3). Earlier studies in man have also shown blunting of NA-stimulated lipolysis in adipose tissue of juvenile diabetics [20] and diminished lipolytic response to NA plus phentolamine in adipose tissue of obese maturityonset diabetics [6]. In the present study, the ability of NA to increase the production of cAMP was abolished in adipose tissue of untreated diabetics. The lipolytic response to NA and also the NA-induced production of CAMP were normalised after antidiabetic therapy. For reasons discussed above the findings with NA are not explained by the action of phosphodiesterase. Instead, they indicate increased $\alpha$-adrenergic receptor sensitivity in subcutaneous adipose tissue of untreated diabetics. Increased lipolytic activity of adrenaline in diabetic rat adipose tissue has recently been observed [30]. The divergent results could be explained by the fact that rat adipocytes seem to lack $\alpha$-receptors [11].

We have observed a strong relationship between glycerol release and tissue cAMP concentration in the presence of ISNA [2] and that the NA-induced peak tissue level of cAMP is correlated with the cell volume of human adipocytes [1]. Therefore, the cAMP data with ISNA and NA were hardly influenced in a significant way by the stroma of human adipose tissue. Since NA and ISNA had divergent effects on glycerol release, the impaired catecholamine induced lipolysis from diabetic human adipose tissue is not explained by alterations in the level of protein kinase or triglyceride lipase.

\section{General Discussion}

Increased basal lipolysis $[21,25,26]$ and increased $\alpha$-adrenergic responsiveness [25] can be demonstrated in subcutaneous adipose tissue obtained from obese patients after starvation. Both phenomena are normalised by refeeding [5]. Increased $\beta$-adrenergic receptor sensitivity in subcutaneous adipose tissue is also observed after starvation [5]. Thus, it is apparent that the metabolism of human adipose tissue is impaired in a very similar way in starvation and in uncontrolled diabetes. It is therefore possible that the findings in untreated diabetes mellitus are secondary to the catabolic state of the disease. However, the patients in this study were unselected and it may be that some of the pathological findings are primarily associated with the diabetic disease.

Acknowledgements. We thank Mrs. Agneta Börjesson, Raija Jönsson, Else-Britt Lundström and Eva Nilsson for their excellent technical assistance. The investigation was supported by grants from the Swedish Medical Research Council (B76-19X-0103410A), Nordic Insulin Fund, Swedish Diabetic Association and Swedish Association for Medical Research.

\section{References}

1. Arner, P.: Studies on the metabolism of human adipose tissue with special reference to the adrenergic control of lipolysis and the metabolism of partial acylglycerols. Thesis. Stockholm: Stål \& Accidenstryck AB 1976

2. Arner, P.: Relationship between intracellular cyclic AMP and lipolysis by human adipose tissue. Acta med. scand. (in press)

3. Arner, P., Arner, O., Östman, J.: The effect of local anaesthetic agents on lipolysis by human adipose tissue. Life Sci. 13, 161-169 (1973)

4. Arner, P., Östman, J.: Methodological aspects of protein-binding assays for cyclic AMP in human adipose tissue. Scand. J. clin. Lab. Invest. 35, 691-697 (1975)

5. Amer, P., Ostman. J.: Changes in the adrenergic control and 
the rate of lipolysis of isolated human adipose tissue during fasting and after re-feeding. Acta. med. scand. (in press)

6. Atkinson, J. N. C., Randle, P. J.: An abnormality of adrenaline, phentolamine stimulated lipolysis in adipose tissue from obese, maturity-onset diabetics. Diabetologia 8, 371-376 (1972)

7. Björntorp, P.: The effect of insulin in vitro on human adipose tissue from normal and diabetic subjects. Acta med. scand. 181, 389-402 (1967)

8. Björntorp, P., Hood, B.: Studies on adipose tissue from obese patients with or without diabetes mellitus. I. Relcase of glycerol and free fatty acids. Acta med. scand. 179, 221-227 (1966)

9. Björntorp, P., Östman, J.: Human adipose tissue. Dynamics and regulation. In: Advances in metabolic disorders. Vol. 5 (eds. R. Levine, R. Luft), pp. 277-327. New York-London: Academic Press 1971

10. Burns, T. W., Langley, P. E.: Lipolysis by human adipose tissue: The role of cyclic $3^{\prime}, 5^{\prime}$-adenosine monophosphate and adrenergic receptor sites. J. Lab. clin. Med. 75, 983-987 (1970)

11. Burns, T. W., Langley, P. E., Robinson, G. A.: Studies on the role of cyclic AMP in human lipolysis. In: Advances in cyclic nucleotide research. Vol. 1 (eds. P. Greengard, G. A. Robinson), pp. 63-85. New York: Raven Press 1972

12. Carlson, L. A., Östman, J.: In vitro studies on the glucose uptake and fatty acid metabolism of human adipose tissue in diabetes mellitus. A preliminary report. Acta med. scand. 174, 215-218 (1963)

13. Carlström, S.: Studies on fatty acid metabolism in male diabetic patients during exercise with a note on the haemodynamics of newly diagnosed, juvenile, male diabetics during exercise. Thesis Acta Universitatis Lundensis, sectio II. No. 20, 1967

14. Chernick, S. S,: Determination of glycerol in acyl glycerols. In: Methods in enzymology, Lipids. Vol. 4 (ed. J. M. Loewenstein), p. 627. New York-London: Academic Press 1969

15. Documenta Geigy: Scientific tables. 6th edition (ed. K. Diem), p. 623 . Basle: J. R. Geigy 1960

16. Efendić, S.: Catecholamines and metabolism of human adipose tissue. III. Comparison between the regulation of lipolysis in omental and subcutaneous adipose tissue. Acta. med. scand. 187, 477-483 (1970)

17. Fredrickson, D. S., Levy, R. J., Lees, R. S.: Fat transport in lipoproteins, an integrated approach to mechanism and disorders. New. Engl. J. Med. 276, 32-44 et seq. (1967)

18. Gilbert, C. H., Kaye, J., Gaiton, D. J.: The effect of a glucose load on plasma fatty acids and lipolysis in adipose tissue of obese diabetic and non-diabetic patients. Diabetologia 10, 135-138 (1974)

19. Gilman, A. G.: A protein binding assay for adenosine 3', 5 '-cyclic monophosphate. Proc. nat. Acad. Sci. (Wash.) 67, 305-312 (1970)

20. Ginsberg-Fellner, F., Knittle, J. L.: Adipose tissue cellularity and metabolism in newly diagnosed juvenile diabetics. Diabetes 22, 528-536 (1973)

21. Goldrick, R. B., Hirsch, J.: Serial studies on the metabolism of human adipose tissue. II. Effects of caloric restriction and refeeding on lipogenesis and the uptake and the release of free fatty acids in obese and nonobese individuals. J. clin. Invest. 43, 1793-1801 (1964)

22. Hirsch, J., Gallian, E.: Methods for the determination of adipose cell size and cell number in man and animals. J. Lipid Res. 9, 110-119 (1968)

23. Ikkos, D., Luft, R.: On the intravenous glucose tolerance test. Acta endocr. (Kbh.) 25, 312-334 (1957)

24. Kissebah, A. H., Fraser, T. R.: The in vitro ${ }^{14} \mathrm{C}$-cyclic AMP production by normal human adipose tissue in response to some hormones and in uncontrolled and controlled diabetic adipose tissue. Horm. Metab. Res. 4, 72-77 (1972)

25. Kjellberg, J., Óstman, J.: Lipolysis and glucose tolerance in obese subjects during prolonged starvation. Acta med. scand. 190, 191-198 (1971)

26. Lisch, H. J., Dittrich, P., Sailer, S., Sandhofer, F., Braunsteiner, H.: Basale und Noradrenaline-(NA)-induzierte Lipolyse in isolicrten Fettzellen des Menschen bei isocalorischer und hypocalorischer Diät. Klin. Wschr. 51, 735-737 (1973)

27. Murad, F., Gilman, A. G.: Adenosine 3', 5'-monophosphate and guanosine $3^{\prime}, 5^{\prime}$-monophosphate: a simultaneous protein binding assay. Biochim. biophys. Acta (Amst.) 252, 397-400 (1971)

28. Sjöström, L., Björntorp, P., Vrána, J.: Microscopic fat cell size measurements on frozen-cut adipose tissue in comparison with automatic determinations of osmium-fixed fat cells. J. Lipid Res. 12, 521-530 (1971)

29. Wieland, O.: Eine enzymatische Methode zur Bestimmung von Glycerin. Biochem. Z. 329, 313-319 (1957)

30. Zapf, J., Feuerlein, D., Waldvogel, M., Froesch, E. R.: Increased sensitivity of diabetic rat adipose tissue towards the lipolytic action of epinephrine. Diabetologia 11, 509-516 (1975)

31. Östman, J.: A procedure for in vitro studies on fatty acid metabolism by human subcutaneous adipose tissue. Acta med. scand. 177, 183-197 (1965)

32. Östman, J.: Studies in vitro on fatty acid metabolism of human subcutaneous adipose tissue in diabetes mellitus. Acta med. scand. 177, 639-655 (1965)

33. Östman, J., Efendić, S.: Catecholamines and metabolism of human adipose tissue. II. Effect of isopropylnoradrenaline and adrenergic blocking agents on lipolysis in human omental adiposc tissue in vitro. Acta med. scand. 187, 471-476 (1970)

Received: February 18, 1976, and in revised form: August 3, 1976

Dr. J. Östman

Karolinska Institute

Dept. of Medicine

Huddinge Univ. Hospital

S-141 86 Huddinge

Sweden 